\title{
The Effects of Dexmedetomidine and Propofol on the Antioxidant System
}

\section{Deksmedetomidin ve Propofol'ün Oksidan ve Antioksidan Sistem Üzerine Olan Etkileri}

Haluk Dülger ${ }^{1}$, Hediye Kelemençe ${ }^{2}$, Uğur Göktaș ${ }^{3}$ M. Ramazan Şekeroğlu², İsmail Katı ${ }^{3}$, Serpil Özcan², Fatma Ç. Baran²

'Selçuk Üniversitesi Meram Tıp Fakültesi, Biyokimya Anabilim Dalı, Konya

${ }^{2}$ Yüzüncü Yıl Üniversitesi Tıp Fakültesi, Biyokimya Anabilim Dalı, Van

${ }^{3}$ Yüzüncü Yıl Üniversitesi Tıp Fakültesi, Anesteziyoloji ve Reanimasyon Anabilim Dalı, Van, Turkey

Eur J Basic Med Sci 2011;1(1):21-27

Received: 31.08 .2010

Accepted: 27.09.2010

Correspondence (Yazıșma Adresi): Prof. Dr. Haluk Dülger Selçuk Üniversitesi Meram Tıp Fakültesi Biyokimya Anabilim Dalı, Konya, Turkey Tel: +90332 2236000 / 7949

E-mail: halukdulger@yahoo.com

\begin{abstract}
The effects of many intravenous drugs, which are used for sedation anesthesia, on free radicals are well known. Two of these drugs are propofol and dexmedetomidine. This study was designed to investigate the effects of dexmedetomidine and propofol on the oxidant and antioxidant systems. Subjects were divided into two groups. Propofol were given to the first group $(n=19)$ and dexmedetomidine to the second group $(n=13)$ for sedation. Blood pressure and heart rate were recorded and serum ALT (alanine aminotransferase), AST (aspartate aminotransferase), creatinine, BUN (blood urea nitrogen), MDA (malondialdehyde), catalase and GSH-Px (glutathione peroxidase) were measured before and 2 hours and 2 days after the drug administration. When propofol and dexmedetomidine groups were compared in terms of blood pressure, heart rate, serum AST, ALT, BUN and creatinin values no statistically significant difference was detected. In propofol group MDA values decreased significantly $(p<0.05)$ and GSH-Px values increased significantly $(p<0.01)$ both in early and late phases following cessation of drug infusion when compared to before infusion. In dexmedetomidine group serum MDA, catalase and $G S H$-Px values did not alter significantly following cessation drug infusion. Propofol was found effective inprevention of oxidative damage and thus decreased serum MDA values and increased GSH-Px levels. Similarly dexmedetomidine had antioxidant effects. However, we thought that more comprehensive work including larger population requires to verify this conclusion.
\end{abstract}

Keywords: Oxidative Stress, antioxidants, propofol, dexmedetomidine 
Özet

Anestezi uygulamasında sedasyon amaciyla kullanılan birçok intravenöz ilacın serbest radikallerle etkileșimi bilinmektedir. Bu ilaçlardan ikisi propofol ve deksmedetomidindir. Bu çalıșmada, deksmedetomidin ve propofol'un oksidan ve antioksidan sistem üzerine olan erken ve geç etkilerinin araștırılması amaçlandı. Çalıșmaya alınan bireyler iki gruba ayrildr. Sedasyon amaciyla, birinci gruba (n:19) propofol, ikinci gruba (n:13) deksmedetomidin verildi. ilaç infüzyonundan önce, infüzyon kesildikten 2 saat sonra ve infüzyon kesildikten 2 gün sonra kan basınçları, kalp atım hızları kaydedildi ve kan örnekleri alındı. Alınan kanlarda serum alanin aminotransferaz (ALT), Aspartat aminotransferaz (AST), kreatinin, kan üre azotu (BUN), malondialdehit (MDA), katalaz ve glutatyon peroksidaz (GSH-Px) düzeyleri çalıșıldı. Propofol ve deksmedetomidin grupları, kan basınçları, kalp atım hızları, serum AST, ALT, BUN ve kreatinin değerleri açısından karșılaștırıldı̆̆ında gruplar arasında anlamlı bir farklılık saptanmadı. Propofol grubunda ilaç infüzyonunun sonlanmasından sonra, MDA değerlerinin gerek erken gerekse geç dönemde, infüzyon öncesine göre anlamlı derecede düștüğü $(p<0.05), G S H-P x$ düzeylerinin ise arttığı $(p<0.01)$ saptandı. Deksmedetomidin grubunda ise; serum MDA, katalaz ve GSH-Px değerlerinde istatistiksel olarak anlamlı bir farklılık gözlenmedi ( $p>0.05$ ). Propofolün oksidatif hasarın önlenmesinde etkili olduğu ve bunun sonucunda serum MDA düzeylerini azalttığı, GSH-Px düzeylerini artırdığı, deksmedetomidinin de buna benzer șekilde antioksidan etkiye eğimli olduğu, ancak bunun daha çok denek içeren çalıșmalarla desteklenmesi gerektiği kanısına varıldı.

Anahtar Kelimeler: Oksidatif stres, antioksidanlar, propofol, deksmedetomidin

\section{GíRiş}

Anesteziklerin, serbest radikallerin zararlı etkilerine karșı dokuların korunmasında oynadıkları roller, son yıllarda hekimlerin ilgisini çekmektedir. Anestezi ve cerrahi girișimler, immün sistemin birçok normal fonksiyonunu bozduğu gibi, bazı anestezikler de özellikle lökosit fonksiyonlarını inhibe etmektedirler (1).

Yoğun bakımda sedatif ilaç ve yöntem seçimini çeșitli faktörler belirler. Anestezik ajanların oksidan/antioksidan etkilerinin araştırıldığı çalışmaların çoğu in vitro veya in vivo hayvan deneyi șeklindedir. İnsanlardaki in vivo çalıșmalar oldukça sınırlıdır (2-4). Serbest radikaller; bir yandan vücudun yapı tașı olarak bilinen protein, lipid ve DNA gibi birçok biyolojik molekülleri okside edebilirken, diğer yandan vücutta doğal olarak bulunan antioksidan savunma sistemleriyle de bu oksidasyona karșı koymaya çalıșırlar. Normal fizyolojik şartlarda bir denge halinde olan bu durum, antioksidan tüketiminin veya serbest radikal oluşumunun artması sonucunda birçok hastalığın patogenezinde suçlanan oksidatif strese yol açar (5-8). Anestezi sırasında ve sedasyon amacıyla kullanılan birçok intravenöz ajanın serbest radikallerle etkileșimi bilinir. Bu ajanlardan ikisi propofol ve deksmedetomidindir.

Propofolün nöroprotektif ve antioksidan özelliğinde, sinaptik transmisyonun inhibisyonununa bağımlı GABA-A'da agonist etkiyle glutamat salıverilmesinin inhibisyonu rol oynamaktadır (9-11). Propofol anestezik konsantrasyonlarda nötrofil polarizasyonunu \% 50 oranında inhibe ederken, daha yüksek konsantrasyonlarda ise tam inhibe eder (12). Jensen ve ark. (13) propofolün; zimozanla uyarılmış insan nötrofillerinde kemotakside azalma ve lökosit migrasyonunda depresyon olușturduğunu bildirmektedirler. Propofolün insanlarda kemotaksi, fagositoz gibi nötrofil fonksiyonlarını baskılama ve reaktif oksijen metabolitlerinin oluşumunu konsantrasyona bağımlı şekilde inhibe etme mekanizması, hücre içi kalsiyum konsantrasyonundaki azalma ile açıklanmıştır (14).

Deksmedetomidin selektif, spesifik ve güçlü a-2 adrenoreseptör agonist etkisiyle (15) respiratuvar sistemi önemli ölçüde etkilemeden anksiyolitik, hipnotik, sedatif, analjezik ve anesteziye destek özellikleri nedeniyle genellikle mekanik ventilasyondaki erișkin hastalarda sedasyon amacıyla kullanılır. Doz bağımlı sempatik sinir sistemi aktivitesinde baskılanma sonucu hemodinamik stabilite $(16,17)$ ve bazen de kontrollü hipotansiyon sağlanması amacıyla kullanılabilir (18). Deksmedetomidin lipid çözünürlüğü nedeniyle lipid membranlara bağlanan enzimlerde yapısal değișikliğe yol açarak süperoksid anyon üretimini bozabilir (19). Diğer yandan, deksmedetomidinin normal ve yüksek plazma konsantrasyonlarında (10 kat ve 100 kat) nötrofillerde fagositozu, kemotaksiyi ve superoksid anyonunun üretimini etkilemediği bildirilmektedir (19).

Insanlar üzerinde propofolün oksidan-antioksidan etkisini araștıran birçok çalıșma bulunmasına karșın, deksmedetomidinle propofolün karşıllaştırıldığı çalıșma bulunmamaktadır. Bu nedenle, deksmedetomidine ve propofol'un oksidan ve antioksidan sistem üzerine olan erken ve geç etkilerinin araștırılması amaçlandı. 
Tablo 1. Propofol grubu hastaların teșhisleri, yandaș hastalıkları ve kullandıkları ilaçlar.

\begin{tabular}{llll}
\hline Hasta no & Teșhis & Yandaș Hastalıklar & Kullanilan Ilaçlar \\
\hline 1 & Intrakranial kanama & - & - \\
2 & Myokard infarktüsü - & - & \\
3 & Serebro-vasküler tromboz & Hipertansiyon & Beloc, Dispril \\
4 & Batın içi apse + Peritonit & - & - \\
5 & Asfiksi Epilepsi Depakin & - & - \\
6 & Polinöropati & - & - \\
7 & Torakal12 fraktürü & Epilepsi & Epanutin \\
8 & Status epileptikus & - & - \\
9 & Bazal ganglionlarda kanama & Epilepsi & Epanutin \\
10 & Intrakranial kanama & - & - \\
11 & Serebro- vasküler patoloji & - & - \\
12 & Bilateral femur kırığı+Yağ embolisi & - & - \\
13 & Serebral kontüzyon & - & - \\
14 & Temporo-paryetal farktür & - & - \\
15 & Serebral kontüzyon & - & - \\
16 & Intoksikasyon & - & - \\
17 & D. mellitus + A. böbrek yetmezliği & - & - \\
18 & Splenektomi & - & \\
19 & Wolf-Parkinson-White sendromu & - & \\
\hline
\end{tabular}

\section{GEREÇ VE YÖNTEM}

Bu çalışma, Üniversitemiz Tıp Fakültesi Hastanesi Anesteziyoloji ve Reanimasyon Anabilim Dalına bașvuran ve Anestezi Yoğun Bakıma alınan 32 hastada gerçekleștirildi. Çalıșmaya alınan hastaların yoğun bakıma kabul edilme nedenleri Tablo 1 ve 2'de gösterilmiștir. Hemodinamisi stabil olmayan; hipovolemi, șok, sepsisi bulunan, propofol ve deksmedetomidine karșı alerjisi olan ve trigliserid düzeyi yüksek olan hastalar çalıșmaya alınmadı.

Yoğun bakım ünitesine alınan hastalara EKG, invazif arter monitörizasyonu, periferik oksijen saturasyonu ve santral venöz kateterizasyonu yapıldı. Sedasyon bașlanmadan önceki ölçülen kan basıncı değerine göre \% 30 veya daha fazla düșmesi hipotansiyon, kalp atım hızının 50 atım dk ${ }^{-1}$ altına düșmesi bradikardi olarak kabul edildi. Hipotansiyon ve bradikardi gelișen olgular, infüzyon dozunun düșürülmesi, infüzyonun sona erdirilmesi, sıvı replasmanı veya $5 \mathrm{mg}$ i.v. bolus efedrin dozlarının verilmesi gibi yöntemler ile tedavi edildi.

Yoğun Bakım Ünitesine alınan ve mekanik ventilatöre bağlanan hastalar iki gruba ayrıldı: Propofol grubu (n:19): $1-3 \mathrm{mg} \mathrm{kg}^{-1}$ iv bolus, $50-100 \mu \mathrm{kg}^{-1} \mathrm{dk}^{-1}$ infüzyon șeklinde verildi. Deksmedetomidin grubu (n:13): 1 $\mu g \mathrm{~kg}^{-1} 10$ dakikada iv bolus, $0,5 \mu \mathrm{g} \mathrm{kg}{ }^{-1} \mathrm{dk}^{-1}$ infüzyon șeklinde verildi. Çalıșmaya alınan ve propofol verilen

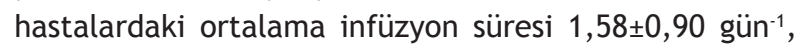

Tablo 2. Deksmedetomidin grubu hastaların teșhisleri, yandaș hastalıkları ve kullandıkları ilaçlar.

\begin{tabular}{llll}
\hline Hasta no & Teșhis & Yandaș Hastalıklar & Kullanılan Ilaçlar \\
\hline 1 & Serebral ödem & - & - \\
2 & Opere intrakranial kitle & - & - \\
3 & Subaraknoid kanama & - & - \\
4 & Subaraknoid kanama & - & - \\
5 & Serebro- vasküler patoloji & KOAH & Foradil, Combivent \\
6 & Intoksikasyon & - & - \\
7 & Intoksikasyon & İlaç bağımlılığı & Eroin \\
8 & Mekanik ikter & - & - \\
9 & Hellp sendromu & - & - \\
10 & Epidural hematom & - & - \\
11 & Opere mide ca & - & - \\
12 & Fulminan hepatit & - & - \\
13 & Splenektomi & - & - \\
\hline
\end{tabular}


Tablo 3. Demografik özellikler (Ort \pm SH)

\begin{tabular}{lll}
\hline & $\begin{array}{l}\text { Propofol grubu } \\
(n=19)\end{array}$ & $\begin{array}{l}\text { Dexmedetomidin grubu } \\
(n=13)\end{array}$ \\
\hline Yaș (Yıl) & $36,95 \pm 3,36$ & $43,97 \pm 4,35$ \\
Cinsiyet & $\begin{array}{ll}\text { Ekek } 13 \\
\end{array}$ & 8 \\
& Kadın 6 & 5 \\
\hline
\end{tabular}

SH: Standart Hata

ve deksmedetomidin verilen hastalardaki ortalama infüzyon süresi ise 2,54 $\pm 2,07$ gün $^{-1}$ idi. Çalıșma yerel etik kurulu tarafından uygun görülmüș olup, hasta veya hasta yakınlarından "Bilgilendirilmiș Olur” alınmıștır.

\section{Kan örneklerinin alınması ve saklanması}

Deksmedetomidin ve propofolün oksidan ve antioksidan sistem üzerine olan erken ve geç etkilerini araștırmak amaciyla; Sedasyona bașlamadan önce (anestezi öncesi, İlaç infüzyonu kesildikten 2 saat sonra (2. saat) - ERKEN, İlaç infüzyonu kesildikten 2 gün sonra (2. gün) - GEÇ olmak üzere toplam 3 defa, her hastadan $5 \mathrm{~mL}$ venöz kan alındı. Her iki ilacın da erken etkilerini gözlemek amacıyla, eliminasyon yarı ömürlerinin 1-3 saat arasında olmasından dolayı, ilaç infüzyonu kesildikten 2 saat sonra kan alındı. Ayrıca geç etkilerini gözlemek amacıyla, vücuttan tamamen metabolize edilerek uzaklașmasını takiben, ilaç infüzyonu kesildikten 2 gün sonra aynı hastadan 3. defa kan alındı.

Alınan venöz kanlar antikoagulansız tüplere boșaltılıp, oda ısısında 20 dakika pıhtılașması beklendi. Pıhtılașan kan 5 dakika süreyle 2000 devirde santrifüj edilip serumları ayrıldı. Elde edilen serumlar çalıșma gününe kadar derin dondurucuda -70 0C'de saklandı. Daha sonra bu serumlarda Malondialdehit (MDA), Katalaz, Glutatyon peroksidaz (GSH-Px), Aspartat aminotransferaz (AST), Alanin aminotransferaz (ALT), Kan üre azotu (Blood urea nitrogen [BUN]) ve Kreatinin düzeyleri ölçüldü.

\section{Serum malondialdehit (MDA) tayini}

Serum MDA düzeyleri Wasowich ve ark.'nın (20) fluorometrik yöntemine göre çalıșıldı. Bu yöntem, tiyobarbitürik asit (TBA) ile MDA- TBA bileșiğinin olușması ve olușan bileșiğin asidik ortamda n-butanol ile ekstraksiyona uğraması ve butanol fazının $525 \mathrm{~nm}$ eksitasyon ve 547 nm emisyon dalga boylarında fluoresansının ölçülmesi esasına dayanmaktadır.

\section{Serum glutatyon peroksidaz (GSH-Px)}

Serum GSH-Px aktivitesi Paglia ve Valentina'nın (21) tanımladığı yöntem modifiye edilerek değerlendirildi. Bu yönteme göre glutatyon (GSSG) oluşum hızı 340 nm dalga boyunda indirgenmiș nikotin amid adenin dinükleotit fosfat'ı (NADPH), NADP'ye yükseltgenmesi sonucu karıșımın optik dansitesinde azalma ile belirlendi.

\section{Serum katalaz}

Serum katalaz aktivitesi Goth'un (22) kolorometrik yöntemine göre ölçüldü. $\mathrm{Bu}$ yöntemde serum $\mathrm{H}_{2} \mathrm{O}_{2}$ subsratiyla inkübe edildi ve reaksiyon amonyum molibdat eklenerek durduruldu. Molibdat ve $\mathrm{H}_{2} \mathrm{O}_{2}$ tarafindan olușturulan sarı renkli kompleksin absorbansı 405 nm'de spektrofotometrede ölçüldü.

\section{Serum AST, ALT, Kreatinin, BUN}

Serum AST, ALT, kreatinin, BUN düzeyleri, kolorimetrik yöntemle çalışan Roche marka ticari kitler kullanılarak Hitachi PP marka modüler otoanalizörde ölçüldü. Bu yöntem, çözelti içindeki madde miktarını çözeltinin renginden faydalanarak ölçme ișlemidir. Kolorimetrik ölçümde, ölçülecek numunenin rengi değișik konsantrasyonlardaki standartların rengiyle karșılaștırılarak değerlendirilir.

\section{Istatistiksel analiz}

İstatistiksel analizler için önce grupların dağılımının normal olup olmadığını incelemek amacıyla One-Sample Kolmogorov-Smirnov testi yapıldı. Veriler normal dağılım göstermediği için ( $p>0.05$ ) verilere non-parametrik testlerden Wilcoxon rank testi uygulandı. Veriler ortalama

Tablo 4. Grupların kan basıncı ve kalp atım hizları (Ort \pm SH).

\begin{tabular}{llll}
\hline & Sistolik kan basınc1 & Diyastolik kan basıncl & Kalp atım hizları \\
\hline Propofol öncesi & $124,74 \pm 5,94$ & $71,32 \pm 4,12$ & $108,21 \pm 5,26$ \\
Propofol 2. saat & $114,29 \pm 4,15$ & $64,29 \pm 3,27$ & $98,93 \pm 6,55$ \\
Propofol 2. gün & $119,44 \pm 5,03$ & $67,78 \pm 3,64$ & $119,33 \pm 8,68$ \\
Deksmed. öncesi & $139,23 \pm 8,20$ & $73,85 \pm 4,61$ & $98,15 \pm 7,67$ \\
Deksmed. 2. saat & $127,00 \pm 10,12$ & $65,00 \pm 6,54$ & $92,10 \pm 8,85$ \\
Deksmed. 2. gün & $122,22 \pm 5,72$ & $62,22 \pm 4,94$ & $103,33 \pm 8,39$ \\
\hline
\end{tabular}

SH: Standart Hata, Deksmed.; Dexmedetomidin 
Tablo 5. Propofol gruplarına ait serum AST, ALT, BUN, kreatinin, MDA, katalaz ve GSH-Px değerleri (Ort \pm SH)

\begin{tabular}{llll}
\hline & Sedasyon öncesi & 2. saat & 2. gün \\
\hline AST $(U L-1)$ & $84,65 \pm 30,18$ & $44,57 \pm 7,30$ & $48,23 \pm 6,79$ \\
ALT $(U L-1)$ & $58,34 \pm 16,27$ & $40,99 \pm 13,91$ & $45,06 \pm 17,48$ \\
BUN (mg $d L-1)$ & $28,31 \pm 6,48$ & $28,74 \pm 7,06$ & $23,09 \pm 2,80$ \\
Kreatinin $(m g d L-1)$ & $0,88 \pm 0,25$ & $1,26 \pm 0,67$ & $0,55 \pm 0,09$ \\
MDA $(\mu m o l ~ L-1)$ & $4,62 \pm 0,24$ & $3,78 \pm 0,39 a^{*}$ & $3,70 \pm 0,58 a^{*}$ \\
Katalaz $(k U L-1)$ & $42,56 \pm 15,57$ & $28,46 \pm 15,12$ & $7,64 \pm 2,41 a, b^{*}$ \\
GSH-Px $(U L-1)$ & $790,50 \pm 107$ & $1875,00 \pm 255,50 a^{* *}$ & $1173,00 \pm 240,00 a^{*}$ \\
\hline
\end{tabular}

SH: Standart Hata, AST: Aspartat aminotransferaz, ALT: Alanin aminotransferaz, BUN: Kan üre azotu (Blood urea nitrogen), MDA: Malondialdehit, kU: Katalaz ünitesi a Anestezi öncesine göre, $b$ 2. saate göre

${ }^{*} p<0.05,{ }^{* *} p<0.01$

\pm standart hata (Ort $\pm \mathrm{SH}$ ) șeklinde ifade edildi. $\mathrm{p}<0.05$

değeri istatistiksel olarak anlamlı kabul edildi.

\section{BULGULAR}

Çalıșmaya alınan bireylerin yaş ortalamaları ve cinsiyetlerinin dağılımı Tablo 3'te verilmiș olup, gruplar arasında anlamlı bir farklılı saptanmadı ( $p>0.05)$. Propofol ve deksmedetomidin grupları, kan basınçları ve kalp atım hızları açısından karșılaștırıldığında gruplar arasında anlamlı bir fark gözlenmedi ( $p>0.05$ ) (Tablo 4).

Propofol grubunda ilaç infüzyonunun öncesine göre infüzyon sonrası gruplarda serum AST, ALT, BUN ve kreatinin değerleri açısından karșılaștırıldığında gruplar arasında anlamlı bir farklılık saptanmadı ( $p>0.05)$ (Tablo 5). Propofol grubu MDA değerleri karșılaștırıldığında, ilaç infüzyonu öncesi MDA değerlerine göre, ilaç sonlandıktan 2 saat ve 2 gün sonraki her iki gruba ait değerlerde anlamlı derecede düșüş gözlendi $(p<0.05)$ (Tablo 5). Propofol grubu katalaz aktivitesi açısından incelendiğinde, ilaç infüzyonu sonlandıktan 2 gün sonraki katalaz değerleri infüzyon öncesi ve 2 saat sonrası değerlere göre anlamlı olarak azaldığı gözlendi $(p<0.05)$ (Tablo 5). Propofol grubu GSH-Px aktivitesi açısından incelendiğinde, gerek infüzyon bittikten 2 saat sonraki değerlerin gerekse 2 gün sonraki değerlerin infüzyon öncesi değerlere göre anlamlı bir șekilde artmıș olduğu gözlendi (sırasıyla $p<0.01$ ve $p<0.05$ ) (Tablo 5)

Deksmedetomidin grubu, serum AST, ALT, BUN ve kreatinin değerleri açısından karşılaștırıldığında deksmedetomidin uygulandıktan 2 saat ve 2 gün sonrası elde edilen değerler ile uygulama öncesi değerler arasında anlamlı bir farklılı saptanmadı ( $p>0.05$ ) (Tablo 6). Deksmedetomidin grubu MDA değerleri açısından incelendiğinde, ilaç uygulamasından sonraki her iki grupta da serum MDA düzeylerinin ilaç uygulanması öncesi değerlere göre azaldığı, ancak bu azalmanın istatistiksel olarak anlamlı olmadığı saptandı ( $p>0.05$ ) (Tablo 6). Deksmedetomidin grubu katalaz aktivitesi açısından incelendiğinde, ilaç infüzyonu sonlandıktan 2 saat ve 2 gün sonraki katalaz değerlerinin ilaç uygulanmasından öncesine göre azaldığı, ancak bu azalmanın istatistiksel olarak anlamlı olmadığı gözlendi ( $p>0.05$ ) (Tablo 6). Deksmedetomidin grubu GSH-Px aktivitesi açısından incelendiğinde, deksmedetomidin uygulaması sonrası değerlerle, uygulama öncesi değerler arasında anlamlı bir farklılığın olmadığı gözlendi ( $p>0.05)$ (Tablo 6).

\section{TARTIŞMA}

Tablo 6. Deksmedetomidin grubuna ait serum AST, ALT, BUN, kreatinin, MDA, katalaz ve GSH-Px değerleri $(\mathrm{Ort} \pm \mathrm{SH})$

\begin{tabular}{llll}
\hline & Sedasyon öncesi & 2. saat & 2. gün \\
\hline AST $(U L-1)$ & $136,60 \pm 36,17$ & $68,65 \pm 24,01$ & $67,87 \pm 18,57$ \\
ALT $(U L-1)$ & $112,97 \pm 33,19$ & $84,44 \pm 28,38$ & $74,94 \pm 22,96$ \\
BUN (mg dL-1) & $35,86 \pm 10,27$ & $42,29 \pm 14,08$ & $46,40 \pm 13,85$ \\
Kreatinin $(m g d L-1)$ & $0,91 \pm 0,21$ & $1,01 \pm 0,31$ & $0,97 \pm 0,28$ \\
MDA $(\mu m o l ~ L-1)$ & $6,22 \pm 0,83$ & $5,07 \pm 0,41$ & $5,22 \pm 0,61$ \\
Katalaz $(k) L-1)$ & $38,55 \pm 19,30$ & $14,79 \pm 3,73$ & $21,87 \pm 11,07$ \\
GSH-PX $(U L-1)$ & $1183,00 \pm 80,50$ & $1715,00 \pm 225,50$ & $1573,00 \pm 305,00$ \\
\hline
\end{tabular}

SH: Standart Hata, AST: Aspartat aminotransferaz, ALT: Alanin aminotransferaz, BUN: Kan üre azotu (Blood urea nitrogen), MDA: Malondialdehit, GSH-Px: glutatyon peroksidaz, kU: Katalaz ünitesi 
Çalıșmamızda propofol grubu ilaç infüzyonu öncesi ve sonrası serum MDA, katalaz ve GSH-Px değerleri karșılaștırıldığında; ilaç sonlandıktan 2 saat ve 2 gün sonraki MDA ve katalaz değerlerinde anlamlı derecede düșüuss, serum GSH-Px düzeylerinde ise anlamlı bir artış gözlenmiștir.

Önceki çalıșmalarda in vitro propofole maruz kalma sonucunda aktive lökositlerden serbest radikal salıverilmesinin bozulduğu, anestezik konsantrasyonlarda propofolün insan nötrofillerinde uyarılmıș solunum patlamasını inhibe ettiği, klinik konsantrasyonlardaki propofolün de fagositoz ve nötrofil polarizasyonunu baskıladığı gösterilmiștir $(9,12,23-26)$. Bunun yanında Davidson ve ark. (27) tarafından propofolün nötrofillerin fagositoz fonksiyonunu ve $\mathrm{H} 2 \mathrm{O} 2$ olușumunu anlamlı șekilde inhibe etmediği bildirilmiștir. Propofolün lipid peroksidasyonuna karșı antioksidan aktivitesi insan plazmasında, sıçan karaciğer mitokondrilerinde, mikrozomlarda, beyin sinaptozomlarında gösterilmiștir $(10,28,29)$. Propofolün izole sıçan kalplerinde hidrojen peroksitle olușturulan lipid peroksidasyonu ve eritrositlerde t-butil hidroksi peroksitin indüklediği malondialdehit oluşumunu inhibe ettiği bildirilmiştir $(28,29,30,31)$. Propofolün antioksidan etkinliğini gösteren birçok çalıșmada oksijen radikallerinin neden olduğu lipid peroksidasyonunun bir ara ürünü olarak ortaya çıkan MDA düzeyi, tiyobarbütirik asit reaksiyonları üzerinden değerlendirilmiş ve MDA düzeyindeki azalma, serbest oksijen radikallerinin azalmasının indirekt göstergesi olarak yorumlanmıștır (32).

Çalıșmamızda, literatürle uyumlu olarak propofolün antioksidan etki gösterdiği, bunun sonucunda serum MDA düzeylerinin azaldığı saptandı. MDA düzeylerinin azalması oksidatif hasarın azaldığının bir göstergesidir. Diğer yandan antioksidan enzimlerden olan serum GSHPx aktivitesinin arttığı, katalaz düzeylerinin ise azaldığı saptandı. GSH-Px düzeylerindeki yükselmenin, artan gereksinimi karșılamak üzere enzim sentezinin daha fazla gerçekleșmesine bağlı olduğu söylenebilir. Ancak antioksidan bir enzim olan katalaz düzeylerini propofolün artırması beklenirken bunun olmadığı, aksine düşürdüğü saptanmıştır. Bunun da propofol tarafından katalaz aktivitesi üzerine mekanizmasını bilemediğimiz bir inhibisyon ile gerçekleșmiş olabileceği kanısına varıldı. Keza Șekeroğlu ve ark. (33) tarafından yapılan depo kanlarında eritrositlerin oksidasyona duyarlılığı ile ilgili invitro çalıșmada da katalaz aktivitesinde bir düșüș saptanmıștır. Ancak bu etkileșimin veya inhibisyonun mekanizmasını ortaya çıkaracak daha detaylı çalıșmalar gerekmektedir. Literatürde deksmedetomidinin antioksidan etkisi ile ilgili çalıșmalar sınırlıdır. Bizim çalıșmamızda, propofol grubundaki sonuçlara benzer şekilde, serum MDA ve katalaz aktivitesinin azaldığı ve serum GSH-Px aktivitesinin ise arttığı saptandı. Ancak bu değișimler istatistiksel olarak anlamlı değillerdi. Bunun nedeni, deksmedetomidin uygulanan gruptaki hasta sayısının az olmasından kaynaklanabilir.

Sonuç olarak, propofolün oksidatif hasarın önlenmesinde etkili olduğu ve bunun sonucunda serum MDA düzeylerini azalttığı, antioksidan enzimlerden katalaz aktivitesi azaltırken GSH-Px düzeylerini artırdığı, deksmedetomidinin ise anlamlı bir antioksidan etki göstermediği, ancak bunun daha çok denek içeren çalıșmalarla desteklenmesi gerektiği kanaatine varıldı.

\section{REFERENCES}

1. Dikmen B, Erk G, Et G, et al. Propofol/Remifentanil anestezisi ile sevofluran anestezisinin insan eritrositlerindeki oksidan ve antioksidan sistem üzerine etkileri. Türkiye Klinikleri J Anest Reanim 2005; 3:5-20.

2. Ansley DM, Lee J, Godin DV, Garnett ME, Qayumi AK. Propofol enhances red cell antioxidant capacity in swine and humans. Can J Anaesth 1998; 45:233-9.

3. Bao YB, Williamson G, Tew D. Antioxidant effects of propofol in human hepatic microsomes: concentration effects and clinical significance. Br J Anaesth 1998; 81:5849.

4. Manataki AD, Tselepis AD, Glantzounis GK, Arnaoutoglou $H M$, Tsimoyiannis EC, Stavropoulos NE. Lipid peroxidation and the use of emulsified propofol in laparoscopic surgery. Surg Endosc 2001; 15:950-3.

5. Foulis $P R$, Sandford BH, Gottfried M. Drug induced morphologic changes in the liver. Ann Clin Lab Sci 1998; 18:215-28.

6. Sinclair AJ, Barnet AH, Lunec J. Free radicals and antioxidant systems in health and disease. Br J Hosp Med 1990; 43:334-44.

7. Maxwell SRJ. Prospects for the use of antioxidant therapies. Drugs 1995; 49:315-61.

8. Günaydın B, Çelebi $H$. Genel anesteziklerin serbest radikaller ve antioksidanlarla ilișkileri. Anestezi Dergisi 2003; 11(2):87-98.

9. Bryson HM, Fulton BR, Faulds D. Propofol. An update of its use in anaesthesia and conscious sedation. Drugs 1995; 50:513-59.

10. Murphy PG, Myers DS, Davies MJ, Webster NJ, Jones JG. The antioxidant potential of propofol $(2,6$, diisopropylphenol). Br J Anaesth 1992; 68:613-8.

11. Green TR, Bennet SR, Nelson VM. Specifiticy and proper- 
ties of propofol as an antioxidant free radical scavenger. Toxicol App Pharmacol 1994; 129:163-9.

12. O'Donnell NG, McSharpy CP, Wilkinson PC, Asbury AJ. Comparison of the inhibitory effect of propofol, thiopentone and midazolam on neutrophil polarization in vitro in the presence or absence of human serum albumin. $\mathrm{Br} \mathrm{J}$ Anaesth 1992; 69:70-4.

13. Jensen AG, Dahlgren C, Eintrei C. Propofol decreases random and chemotactic stimulated locomotion of human neutrophils in vitro. Br J Anaesth 1993; 70:99-100.

14. Mikawa K, Akamatsu H, Nishina K et al. Propofol inhibits human neutrophil functions. Anaesth Analg 1998; 87:695700.

15. Duke P, Maze M, Morrison P. Dexmedetomidine: a general overview. International Congress and symposium series Redifining Sedation 1998; 221:11-22.

16. Ebert TJ, Hall JE, Barney JA, Uhrich TD, Colinco MD. The effects of increasing plasma concentrations of dexmedetomidine in humans. Anesthesiology 2000; 93:382-94.

17. Talke $P$, Chen $R$, Thomas $B$, et al. The hemodynamic and adrenerjic effects of perioperative dexmedetomidine infusion after vascular surgery. Anesth Analg 2000; 90:8349.

18. Tobias JD. Controlled hypotension in children: A critical review of available agents. Pediatric Drugs 2002; 47:43953.

19. Nishina $K$, Akamatsu $H$, Mikawa $K$, et al. The effects of Clonidine and Dexmedetomidine on Human Neutrophil Functions. Anesth Analg 1999; 88:452-8.

20. Wasowicz W, Nève J, Peretz A. Optimized steps in fluorometric determination of thiobarbituric acid-reactive substances in serum: importance of extraction $\mathrm{pH}$ and influence of sample preservation and storage. Clin Chem 1993; 39(12):2522-6.

21. Paglia DE, Valentive WN. Studies on the avantitaue and gualitative characterization of erytrocyte glutathione peroxidase. J Lab Clin Med 1967; 158-69.

22. Goth L. A simple method for determation of serum catyalase activation and revision of reference range. Clin Chim Acta 1991; 196:143-51.

23. Noronha-Dutra AA, Epperlein MM, Woolf N. Reduction of nitric oxide with hydrogen peroxide to produce poten- tially cytotoxicsinglet oxygen as a model for nitric oxidemediated killing. FEBS Lett 1993; 321:59-62.

24. Moudgil GC. Effects of premedicants, intravenous anaesthetic agents and local anaesthetic on phagocytosis in vitro. Can Anaesth Soc J 1981; 28:597-602.

25. White IWC, Gelb AW, Wexler HR, Stiller CR, Keown PA. The effects of intravenous anaesthetics agents on human neutrophil chemiluminescense. Can Anaesth Soc J 1983; 30(5):506-11.

26. Krumholz W, Endrass J, Hempalmann G. Propofol inhibits phagocytosis and killing of Staphylocossus aureus and Ecshericia Coli by polymorhonuclear leukocytes in vitro. Can J Anaesth 1994; 41:446-9.

27. Davidson JAH, Boom SJ, Pearsall FJ, Zhang P, Ramsay G. Comparison of the effects of four i.v. anaesthetic agents on polymorhonuclear leucocyte function. $\mathrm{Br} J$ Anaesth 1995; 74:315-8.

28. Aarts L, Van Der Hee R, Dekker I, De Jong J, Langemeijer $H$, Bast $A$. The widely used anesthetic agent propofol can replace a tocopherol as an antioxidant. FEBS Lett 1995; 357:83-5.

29. Mussachio E, Rizzoli V, Bianchi M, Bindoli A, Galzigna L. Antioxidant acction of propofol on liver microsomes, mitochondria and brain synaptosomes in the rat. Pharmacol Toxicol 1991; 69:75-7.

30. Kahraman S, Demiryürek AT. Propofol is a peroxynitrite scavenger. Anesth Analg 1997; 84:1127-9.

31. Kokita N, Hara A. Propofol attenuates hydrogen peroxide mechanicaland metabolic derangements in the isolated rat heart. Anesthesiology 1996; 84:117-27.

32. Toivonen HJ, Ahotupa M. Free radical reaction products and antioxidant capacity in arterial plasma during coronary artery bypass grafting. J Thorac Cardiovasc Surg 1994; 108:140-7.

33. Sekeroğlu MR, Huyut Z, Dulger HH, Dilek I. The susceptibility of autoxidation of erythrocytes during storage of Blood: Effects of melatonin and propofol. AACC Annual Meeting \& Clinical Lab Expo, Clinical Chemistry (Supplement), Washington DC, 2008; Vol.54(6), A-28. 